\title{
Japanese Exchange Students' Writing Experiences in a Canadian University
}

\section{Ling Shi and Gulbahar H. Beckett}

This study investigated the learning experiences of 23 Japanese students in a one-year Academic Exchange Program at a Canadian university. The participants wrote either an opinion task or a summary task at the beginning of the program using two preselected source texts. They then revised the drafts at the end of the program and were interviewed to comment on what they had learned about English writing during their study in Canada. Analyses of the interview data and comparisons of the original and the revised texts indicate that participants revised their drafts to use more words of their own and to follow the more direct English style and linear rhetoric pattern. The narrative of how these students adopted English writing conventions and their perceptions of whether they would continue to use them when they returned to Japan suggests an impact of English training not only on their English but also on their Japanese academic writing.

Cette étude s'est penchée sur l'apprentissage de 23 étudiants japonais participant à un programme d'échange dans une université canadienne. Au début du programme, les participants ont écrit un texte d'opinion ou un résumé de texte à partir de deux textes présélectionnés. Un an plus tard, à la fin du programme, ils ont révisé leur brouillon et ont passé une entrevue pour expliquer ce qu'ils avaient appris sur la rédaction anglaise pendant leur séjour d'études au Canada. Ensemble, l'analyse des données d'entrevues et la comparaison du texte original et la version révisée ont révélé que les étudiants avaient modifié leur brouillon pour ajouter davantage de leurs propres expressions et pour suivre de plus près la structure rhétorique linéaire de l'anglais. La façon dont ces étudiants ont adopté les conventions de la rédaction anglaise d'une part, et leurs perceptions quant à la possibilité de continuer à les employer après leur retour au Japon d'autre part, nous indiquent que l'impact de leur formation en anglais ne se pas fait uniquement sentir sur leurs rédactions en anglais mais aussi sur leurs rédactions en japonais.

\section{Introduction}

With English becoming a world language, an increasing number of international students are seeking undergraduate studies in North American universities. Following this trend is a growing body of research on the acculturation of these second-language students into the English-language 
academy. Issues emerging from the research concern how non-native English-speaking undergraduates struggle to survive in a new education system, how their first-language writing conventions influence their English writing, and whether training in English writing changes how they write in their first language. To further pursue these issues, this study interviewed a group of Japanese students at the end of their eight-month academic exchange program in a large Canadian university. The students were asked to comment on their writing experiences based on a comparison between two pieces of their writing, one completed at the beginning and the other at the end of their eight-month program. The purpose was to explore how these Japanese students' writing experiences in an English-speaking university had improved their English writing and might change how they would write, in either English or Japanese, when they returned to Japan.

\section{Literature Review}

Earlier studies have documented the development of international undergraduates and their strategies in dealing with the challenges of academic writing. Two studies conducted by Smoke (1994) and Spack (1997) suggest that students who use writing as a tool to understand and analyze what they are learning and reading move away from repeating the authors' words to express complex ideas in their own words and voices. Other studies, instead of exploring how writing is used as a tool of learning, examined how it is tackled by students using various strategies. In dealing with the demands of writing, some students, as Leki (1995) reported, used various strategies such as relying on previous writing experiences in completing their assignments, taking advantage of their knowledge of first-language culture to compensate for their linguistic and educational disadvantages, using feedback and models to guide their studies, and resisting teachers' demands to control their own fate. In addition, the strategy of copying was observed by Currie (1998) based on the case of a Chinese student who survived an undergraduate course by copying extensively in her writing assignments. Examining the writing experiences of international students, viewed as either a learning tool or a challenge, is key to understanding the processes and outcomes of their academic studies.

Researchers who explored international students' writing experiences have suggested that some of the writing strategies, such as copying, can be traced to students' educational backgrounds in their home countries. For example, Vietnamese students might depend on models for writing assignments because that was how they learned English: to reproduce memorized models (Johns, 1991). Similarly, Iranian students who believe written language is meant to be duplicated and that the purpose of writing is to display knowledge generated by others might repeat the same ideas using the same phrases and sentences across different essays (Ray, 1990). Such dependence 
on source texts and models, as Spack (1997) suggests, could stem from students' lack of independent and creative learning experiences required in North America. The impact of these students' educational backgrounds in their learning experiences also leads to a concern for the influence of first-language writing conventions on English writing.

Researchers who do cross-cultural comparisons of writing conventions mostly focus on professional academic writing in English and other languages (Bloch \& Chi, 1995; Connor, 1999; Clyne, 1987; Hinds, 1987; Taylor \& Chen, 1991; Thatcher, 2000; Vassileva, 2001). Only a few have observed distinct rhetoric patterns in the English writing of non-native English undergraduates. Among them Kaplan (1966) examined about 600 English expository essays written by international students and found some preferred composition styles and organization patterns that differed from the linear English rhetoric pattern that features a statement of purpose followed by an orderly presentation of arguments and supporting details. For example, Asian students were observed to use an indirect approach by commenting on the topic from different perspectives. Students with a Chinese background, as Matalene (1985) found, tend to offer assertions rather than proofs, a common style in Chinese writing. Arabic undergraduates have been observed to transfer "the long-winded approach" or "flowery introduction" from Arabic discourse into their English writing for science and technology (Halimah, 2001). The nonlinear or indirect approach found in these non-native English students' writing suggests a rhetorical tradition that assumes the readers' primary responsibility in written communication (Hinds, 1983; Kachru, 1995). In support of this observation, Scarcella (1984) reported that non-native English students are limited in orienting readers in their writing, whereas native English students employ a variety of linguistic devices to engage readers' attention.

Contrastive rhetoric, although highlighting some special characteristics and needs of ESL students, has been criticized in terms of its tendencies (a) to view language and culture as static rather than dynamic, (b) to overgeneralize cultural characteristics based on isolated examples, and (c) to overlook the similarities in text structures between languages (Bloch \& Chi, 1995; Kirkpatrick, 1997; Kubota, 1997; Leki, 1997; Taylor \& Chen, 1991; Zamel, 1997). Contrary to contrastive rhetoricians who suggest negative transfers from first languages, Mohan and Lo (1985) argue that the organizational problems in the writing of non-native English students are developmental. Other researchers dispute this notion, suggesting either similar strategies shared by second-language (L2) and first-language (L1) writers (Campbell, 1990; Connor \& Kramer, 1995) or different writing processes among students from the same culture (Cumming, 1989; Sasaki, 2000).

More research, therefore, is needed to clarify the role of first-language writing conventions in the writing of non-native English-speaking students, 
especially at the undergraduate level when these students are just starting to write English essays in various academic disciplines. Although no research has directly examined the impact of the learning and writing experiences of international undergraduates after they return home, findings from related studies have shed light on this potential research area. For example, based on their data from Chinese speakers in academic and pre-academic English courses, Carson and Kuehn (1992) found that students' first language discourse competence might decrease as their English discourse competence increases. In another study, Jones (1997) reports that when returning home to work, some Japanese undergraduates felt they were more direct and able to state their opinions more clearly than their co-workers. In addition, Eggington (1987) notes that many Korean scholars with a background of English training retain English rhetorical structures when writing in Korean. Similarly, Shi (in press) documents the reflections of some Western-trained Chinese professors on the different rhetoric conventions in Chinese and English expository writing and their preference to follow the English style in Chinese writing. Findings to date imply that further research is essential to identify the role of international students and their contributions to the spread of English writing conventions in their home environment.

The above review suggests that the impact of academic training on the writing experiences of international students is an important research area. Such research could inform Western/American writing instructors and academic staff about the possible impact of cultural factors on rhetoric and plagiarism. As indicated in earlier research, students who are trained in their L1 education to believe that written language is meant to be duplicated might rely on copying when writing their English essays (Ray, 1990). In addition, research on the impact of academic training could provide insights into a transition in writing styles that international students undergo and the implications this transition has on their future writing in either English or their home languages after they return home. Motivated by these pedagogical needs, we designed this study to focus on the following three research questions:

1. What do international undergraduates learn about English writing in a North American university?

2. What kind of awareness, if any, do non-native English-speaking undergraduates develop about English writing conventions as a result of training in an English-speaking university?

3. How do international undergraduates perceive the impact of English writing experiences on how they will write, in either English or Japanese, after returning to their home country or university? 


\section{Method}

\section{Participants}

Volunteers were solicited from 99 Japanese students enrolled in an eightmonth academic exchange program in a large Canadian university from September 2000 to April 2001. Typically between 19 and 21 years of age, all the exchange students were in their second or third year of undergraduate studies in various disciplines. Most were enrolled in an eight-month sheltered program that offers a blend of English language and content instruction. The content-based courses offered in the program included Introduction to Canadian Studies, Language Across the Curriculum, Arts Studies, and Introduction to Social Sciences and Educational Research. Based on their performance in the first term, some students were encouraged to take one or two regular courses in their discipline in the second term. The exchange students earned credits toward their undergraduate degree at their home university in Japan.

Students who volunteered to participate in the study were asked to write either a summary or an opinion essay at the beginning of the program and then revise it at the end of the program (a period of eight months). Those who completed both drafts were invited to respond to a set of interview questions about their learning and writing experiences either face-to face or via e-mail. (E-mail correspondence was encouraged for those who could not attend the face-to-face interviews.) Although many students (over 50) initially participated in the study, this article reports data analyses from 23 participants who completed both the first and second drafts and also responded to the interview questions. Table 1 presents profiles of these students. Based on their Test of English as a Foreign Language (TOEFL) scores before and at the end of the exchange program, the participants had improved an average of 19 points as a result of their training in Canada. Most of the participants (21) were female and all but one majored in arts. (Of the 99 students in the exchange program, 76 were women and 98 majored in arts.) Among the 23 participants in the study, 14 did the opinion task and nine did the summary task. With regard to the interview questions, 15 students responded to them face-to-face and eight sent written responses via e-mail.

\section{Writing Tasks}

At the beginning of their exchange program at the Canadian university in September 2000, the participants wrote either an opinion or a summary task on the issue of euthanasia using two preselected source texts from Biskup and Wekesser (1992) (see Appendix A for task instructions and source texts). The tasks were designed to resemble the writing demands of university course assignments that typically involve summarizing and commenting on information from source readings. The second author, who was teaching in 
Table 1

Participants' Profile

\begin{tabular}{lllllll}
\hline ID & Sex & Major & $\begin{array}{l}\text { TOEFL } \\
\text { score } \\
\text { before the } \\
\text { program }\end{array}$ & $\begin{array}{l}\text { TOEFL } \\
\text { score at } \\
\text { the end of } \\
\text { the program }\end{array}$ & Task & Interview \\
& & & & & & \\
\hline P1 & F & Law & 497 & 533 & Opinion & Face-to-face \\
P2 & F & Law & 490 & 487 & Opinion & Face-to-face \\
P3 & F & International Relations & 487 & 517 & Opinion & Face-to-face \\
P4 & F & Policy science & 507 & 537 & Opinion & Face-to-face \\
P5 & F & Law & 483 & 520 & Opinion & Face-to-face \\
P6 & F & Social Sciences & 510 & 550 & Opinion & Face-to-face \\
P7 & M & Science \& Engineering & 517 & 543 & Opinion & Face-to-face \\
P8 & F & Economics & 483 & 500 & Opinion & E-mail \\
P9 & F & Social Sciences & 473 & 490 & Opinion & E-mail \\
P10 & F & International Relations & 543 & 537 & Opinion & E-mail \\
P11 & F & Social Sciences & 533 & 557 & Opinion & E-mail \\
P12 & F & Social Sciences & 520 & 520 & Opinion & E-mail \\
P13 & F & Social Sciences & 490 & 497 & Opinion & Face-to-face \\
P14 & F & Social Sciences & 517 & 537 & Opinion & Face-to-face \\
P15 & F & International Relations & 493 & 540 & Summary & Face-to-face \\
P16 & F & Social Sciences & 483 & 537 & Summary & Face-to-face \\
P17 & F & International Relations & 497 & 527 & Summary & Face-to-face \\
P18 & M & International Relations & 537 & 523 & Summary & Face-to-face \\
P19 & F & Social Sciences & 563 & 537 & Summary & Face-to-face \\
P20 & F & Letters & 483 & 527 & Summary & E-mail \\
P21 & F & Letters & 533 & 527 & Summary & E-mail \\
P22 & F & Social Sciences & 483 & 497 & Summary & E-mail \\
P23 & F & International Relations & 497 & 510 & Summary & Face-to-face \\
\hline & Mean score & 505 & 524 & & \\
\hline
\end{tabular}

the exchange program, administered the tasks in her Language Across the Curriculum class in Term 1. At the end of the program, participants were given back their drafts to revise outside class hours. To encourage student participation, a research assistant who was a graduate student in the area of second language writing read the two drafts carefully and offered individual conferences for feedback. The conferences were conducted after the interviews so that the feedback did not influence students' reflections. 


\section{Interviews}

A total of 15 students participated in the face-to-face interviews, which were shared between the first author and the research assistant. The interviews, each lasting about an hour, were semistructured and conducted in English. All the interviews were audiotaped, transcribed, and, together with the e-mail responses (also in English) from the eight other students, were analyzed in the light of the three research questions. Students' written drafts were then analyzed to verify their comments and reflections. Compared with the spoken responses from the interviews, the e-mail responses were brief. We could not ask these students to elaborate on their views because by the time we received and started to analyze the comments, they had all finished the program and were preparing to leave the country. Corresponding to the three research questions, the following are the main prompts used in both face-to-face interviews and e-mail correspondence:

1. Can you comment on how you revised the text and why you made those changes? Based on those changes, please comment on what you have learned during your studies in Canada.

2. Did you notice any differences between what you learned in Japan and in Canada in terms of academic writing? If you did, what are they?

3. What do you see as some of the impacts of English training on your writing, in either English or Japanese, after you return to Japan?

\section{Findings and Discussions}

\section{Learning to Write in a Canadian University}

When asked how they revised the drafts and what they had learned, all 23 participants expressed their belief that they had improved their English academic writing in Canada. Eighteen of the 23 participants felt that it was easier and faster doing the reading and writing the second time. These students also noticed that they had moved away from depending on the source texts for words and expressions in their first drafts to using their own words in their second drafts. The following quotations show how these students copied extensively when writing the first draft because of problems in comprehending the source texts.

P1: It was so hard the first time. The topic is complicated and ... there are a lot of new words. The second time ... it is easier to understand.... But the first time, I think I used authors' words in the article just because I didn't understand the meaning of the words... I just copied them.... I just couldn't say the same thing with my words.

P7: Since I did not really understand what each paragraph said [the first timel, so I couldn't really say my opinion. Because I couldn't under- 
stand, so I think I used some of the phrases and sentences [from the source texts].

Compared with their first writing experience, many students said that because it was easier to comprehend the source texts the second time, they were able to use more words of their own when rewriting the drafts.

P3: I think I did not use the original paper so much [the second time] ... I tried to use my own words.

P23: Before I intended to copy the sentences or words. But now I can paraphrase, like use different words that have the same meaning.... That's the main difference, I think.Trying to use their own words in the second drafts, some students said that they came to understand the importance of using references and doing research to form their own voices in writing academic essays. In this regard, several students contrasted their experiences in Canada with those in Japan. In the following comments, one student ( $\mathrm{P} 4$ ) says that she learned to use writing as a tool to apply what she had learned rather than display what she knew as she did in Japan; whereas another student (P6) critically reflects on how she used to "plagiarize" when writing for Japanese professors. In their own words,

P4: I learned a lot of things... We need the evidence to explain our opinion by the way of reference, quotations, and so on. In Japan, in our paper, it is more important to show the amount of the knowledge we mastered from the lecture and how deep we know about this topic [rather] than what we think about this topic. But in Canada what we think about the lecture and how we should make use of it are required in our paper.

P6: In Japan, nobody cares [about copying]. Even professor doesn't care about it. I just take some words and use them. I always did that.

Nobody told me [not to] so I guess it was OK.... I don't know why Japanese university doesn't mention about plagiarism because obviously many of my friends including me always do plagiarism. That's the easiest way to finish our essay. And nobody cares. I got A.

The avoidance of plagiarism or an effort to use one's own words is evident in the participants' second drafts. The two examples, in Tables 2 and 3 , compare the source sentences and students' sentences in their first and second drafts. Both examples illustrate how the two students (P16 and P15) summarized the source ideas in their first drafts by copying some of the original sentences. The awkward sentence produced by P15 in her first draft suggests that she might not have understood the original text while trying to integrate copied words with her own words. As one student (P4) explained 
Table 2

Comparison of Source Sentence and Student Sentence in the Drafts of P16

Source sentence from Excerpt One
Sentence from the first draft of $P 16$
Sentence from the second draft of P16
The physician should follow
these principles without
exaggerated concern for legal
consequences.
And most important thing is that the physicians should

follow these principles without exaggerated concern for legal prosecution.
However sometimes physicians hesitate to assist suicide because they think this support is against the principle of medical ethics.

Table 3

Comparison of Source Sentence and Student Sentence in the Drafts of P15

\begin{tabular}{lll}
$\begin{array}{l}\text { Source sentence from } \\
\text { Excerpt Two }\end{array}$ & $\begin{array}{l}\text { Sentence from the first draft } \\
\text { of P15 }\end{array}$ & $\begin{array}{l}\text { Sentence from the second } \\
\text { draft of P15 }\end{array}$ \\
\hline $\begin{array}{l}\text { Some patients, moreover, } \\
\text { may feel an obligation to } \\
\text { choose death to spare their } \\
\text { families the emotional and } \\
\text { financial burden of their care. }\end{array}$ & $\begin{array}{l}\text { Moreover, it should be } \\
\text { considered patients decide } \\
\text { their suicide to the point of } \\
\text { the emotional and financial } \\
\text { burden of their families. }\end{array}$ & $\begin{array}{l}\text { Moreover, the reason } \\
\text { patient's wish towards } \\
\text { assisted suicide should be } \\
\text { considered because patients } \\
\text { might choose assisted suicide } \\
\text { when they care about their } \\
\text { family. }\end{array}$ \\
\hline
\end{tabular}

earlier, copying was commonly used when students had problems comprehending the meaning of the original sentence. Compared with how they copied when writing the first drafts, both students (P16 and P15) revised the sentences in their second drafts using their own words. We highlight those strings of words that are identical in the source sentence and the student sentence.

The evidence that the participants were trying to use their own words in their second drafts suggests important progress in these students' English writing. Consistent with earlier findings (Smoke, 1994; Spack, 1997), this study suggests that for many international undergraduates, learning to write from sources is a process that begins with copying or relying on source texts and progresses to expressing ideas using their own words. In contrast to other L2 students who were not sure whether they had any words of their own (Pennycook, 1996), the participants in this study seemed to have developed confidence in claiming ownership of words in their second language. Such confidence could be a result of the eight-month immersion program in the Canadian university. It is also possible that the change is an artifact of explicit instruction with regard to plagiarism and rhetorical structure in English classes. As the participants tried to use their own words in their 
writing, they also became critical of their learning experiences in their home university where copying is common and writing is used to display knowledge. Adding to the previous finding that students might use strategies based on their first language educational backgrounds (Johns, 1991; Ray, 1990; Spack, 1997), this study also suggests that English training experience can in turn cultivate in international students a critical perspective toward the education system and practice in their home country.

\section{Awareness of Contrastive Rhetoric Between English and Japanese Expository Writing}

Comparing their writing experiences in Japan and in Canada, 15 of the 23 participants said they became aware of differences in expository writing between English and Japanese. This awareness was evident when participants compared the organization patterns and styles of their first and second drafts. One student (P18) said that he learned the format of English academic writing in Canada, and two (P16 and P12) described how they revised the organization of their first drafts at the end of the exchange program. In order to improve their writing in the second drafts, P16 paid more attention to organization, whereas $\mathrm{P} 12$ added more supporting ideas to strengthen her argument.

P18: I never did English academic writing in Japan. I had only studied what is supporting sentence, what is paraphrase, and quotation but I never wrote. That's why I did not realize what academic writing was. But when I came here, I realize that kind of format.

P16: In the second [draft], I paid more attention how to write ... and tried to follow the structure.... I think in the first one, I couldn't build the outline in my mind.

P12: This time I just added more opinion to reinforce my main idea to the essay I wrote last time.... Because I felt that the last essay didn't have enough comments to support my idea.

In explaining why they made these structural changes in their second drafts, many participants said they believed that the revisions resulted from a conscious switch from the indirect Japanese style to the direct English style. The interview data suggest that students' awareness of the differences between English and Japanese expository conventions developed as a result of their training in Canada. The following two comments illustrate how students came to realize that the introduction in an English essay was actually the conclusion in a Japanese essay:

P2: In English introduction, there is some kind of conclusion... The [English] introduction has a specific idea.... But in Japanese essay we write and narrow down to a conclusion [the specific idea]. 
P12: I think the most difference between Japanese and Canadian academic writing is where to put my main idea.... Canadian writing writes a conclusion at first and then describes the reason. But in Japanese the conclusion is written after describing the reason. I think this difference is related to each cultural background. Japanese tend to avoid saying something clearly, directly... In Canadian style, the main thesis should be clear, simple and easy for everybody to understand because it is put in the beginning before people read a reason.

Another student (P14) mentions the Japanese ki-shoo-ten-ketsu rhetoric pattern (Hinds, 1983). In contrast to the English pattern, there is a ten, an abrupt turn, to some indirectly related subtheme before the conclusion. As the student put it:

P14: In the Japanese structure, first is the beginning, second is the opinion, and the third part must change the opinion or opposing it ... and then conclusion. So [there are] four parts.

Compared with the above focus on differences between organization patterns, some participants contrasted the direct and indirect styles in the writing of English and Japanese:

P7: I noticed how simply [directly] it is written in English, and how indirectly it is written in Japanese.... I think that is one of the Japanese characteristics. They prefer that because it is a way to make it stronger.

P13: I think the differences of writing styles are reflected by cultural differences. Japanese are often recognized that they like to imply something ... indirectly. On the other hand, Canadians want to know just yes or no.... In Canadian academic writing, we are preferred to state our opinions first and clearly.

P23: In my case, I changed. I wrote English essays more clearly to say my opinions. But I didn't do that in Japanese....In Japanese essay, we don't have to say our opinion clearly.

Like P23, many participants said they consciously followed the direct style when writing English essays during their studies in Canada. To illustrate how these students switched from Japanese conventions to the direct English style and linear organization pattern, the following are the first and second drafts of one student (P13). In her first draft, the writer followed the Japanese style, which starts with an introduction of the two sides of an argument and then ends with her own opinion. In stating her opinion in the conclusion, the writer indirectly addresses the issue of whether physicians can assist suicide by saying that physicians should not support a patient's decision to choose assisted suicide. Stating one's opinion indirectly and also only in the conclusion, as some participants explained in comments cited 
above, is typical in Japanese writing. However, when writing the second draft, the writer moved her statement of opinion to the beginning of the essay and then provided the reasons for her argument. This time the writer's opinion is clearly stated: physicians can ethically assist in suicide. As the writer herself reflected in the interview, "[The second time] I tried to say my opinion in the first line.... I thought it had to be clearer than before." In the following example, the opinion statements in the two drafts are highlighted for easy comparison. The student's drafts, except spelling errors, are presented verbatim.

\section{First Draft of P13}

Can physicians ethically assist in suicide? There are two arguments for this problem. Sidney $\mathrm{H}$, Wanzer et al is for this problem. He thinks physicians should use narcotics in order to ease patients' pain. Sometimes physicians are afraid of being killer by using medication, which lead them death. However, physicians think pain relief is the most important treatment or patients. On the other hand, David Orentlicher is against the opinion. He regards giving medication for pain relief as helping patients' suicide. This action will make relationship between patient and physician worse. The reason why patients choose suicide is they do not want others have distress. The problem is that suicide is implemented not by patients themselves but physicians. Patients have the right for deciding their lives. Therefore, physicians should not assist their reflection of suicide.

Second Draft of P13:

Can physicians ethically assist in suicide or not? I think they can because physicians have the responsibility to ease pain from patients. As Sidney $\mathrm{H}$. Wanzer et al. say, physicians should do whatever patients feel comfortable. In order to do that, sometimes they may recommend patients take narcotics or other medications. However, helping in suicide will lead physicians to serious risks of exorbitant fault and indictment. On the other hand, David Orentlicher agrees with the opposite side. He thinks physicians cannot ethically assist suicide and he consists physicians should precede patients' opinion. Patients feel bad not only from the pain itself but also peoples' help when they decide to. Therefore, we should think who is more important to make decision of death, physicians or patients? It is natural for physicians to make decision because they have the responsibility for patients.

These findings support earlier research on contrastive rhetoric between English and other languages. As the participants reflected, there appears to be an indirect composition style and nonlinear organization pattern in Japa- 
nese writing that is different from English expository rhetoric (Hinds, 1983, 1987). Most participants, when commenting on the direct English style and its linear rhetoric pattern, felt that the English style is clearer and preferable to the Japanese style. Comparison of their drafts suggests that participants switched from the Japanese to the English style after an eight-month immersion in the preferred discourse features of written English. It is interesting to note how quickly these international undergraduates adapted to the English writing style. As previous researchers have noted, Asian readers with no English training background find information presented in the English rhetoric pattern difficult to comprehend even when it is written in their first language (Eggington, 1987; Shi, in press). Further research is required to explore how international students change their rhetoric values as a result of training in English-speaking universities.

\section{Impact of Training in English Writing}

With their awareness of the different writing conventions between Japanese and English and a preference for the English style, the question follows as to how these participants perceived the impact of their training in Canada when they returned to study in their home university. An analysis of the interview data shows that 13 of the 23 students said they would apply what they had learned in Canada and would follow the English writing conventions in their Japanese writing. The following are three examples of the students' responses:

P2: For me, English way of writing is more suitable because I learned a lot here and I always like the way.

P13: I come to like Canadian writing style because "making it clear" can appeal to the reader more. Now I try to say my opinion first and clearly even though it is Japanese writing.

P12: Maybe I will remove ambiguous phrases and try to write my idea more directly.

Several students mentioned particularly that they would follow English citation conventions. The following are two examples.

P15: I didn't pay much attention about citation when I wrote in Japan, but I am going to pay attention to it.

P20: I think my writing maybe changed because of the influence from English. For example, in English writing, we have to cite or paraphrase from other books, but we have never done that [in Japanese]... I will follow the English APA style.

Five of the 23 students said that they were not sure about which format to follow after they returned to Japan. As the following two comments illus- 
trate, one student (P6) said that she would be confused and scared if she practiced "plagiarism" again in Japanese writing; another student (P23) expressed the concern that she might not get good marks if she followed the English style.

P6: I think I am going to get confused. If he or she [the professor] allows me to plagiarize, I don't know. I am so afraid. I am so afraid to go back to Japan to write an essay in Japanese.... I will get really confused. I don't know what to do, and I don't want to do plagiarism.

P23: I might write in the English style in Japanese, but I might not get good marks... I can say my opinion more than before, but I am not sure if professor wants us to do this. In my imagination, Japanese professors don't like opinion essays [essays that state ones' own opinions].

Two other students (P16 and P15), who shared the above concerns, said they would switch between the two styles based on the topic and the professor:

P16: Maybe depends on the topic and the professor. If she suggests us how to write, I have to follow that style.

P15: It depends.... As long as I am thinking about something in Japanese, it is good to follow the Japanese way to write... In Japan, I think there are two options. I can follow either the English way or the Japanese way. It depends on the situation, what my professor asks me to do.

Of the 23 participants, five students said they would return to how they wrote in Japanese when in Japan. The reason, as the following quotations illustrate, is that the English style might not be accepted by a Japanese audience.

P14: When I am in Japan, I will follow the Japanese way.... If I say my own opinion, they think I am selfish. After I go back to Japan, I am afraid I have to switch back....Maybe people in Japan do not know this way of thinking. I cannot communicate with them in this way.

P7: I am not going to write in that direct way, I think, because people might not accept it.

P21: I can't change the Japanese way of academic writing like [to] that of the Canadian way. Teachers might think that my writing is too direct. I have to be careful.

The above finding suggests that when they return to their home university to write in Japanese, the participants face a choice between the English style that appeals to most international readers, the Japanese style that is accepted by local readers, or applying either to the appropriate context. The various choices made by the participants imply a critical awareness and 
examination of their place between global and local values. Over half the participants (13) had modified their rhetoric values and become more comfortable with the English style. After returning to Japan, as Berwick and Carey (2000) report from their survey of 169 students from the same exchange program, these students need to recover their sense of Japanese identity. Compared with those who planned to follow the English style, other students were concerned that the English style might not be accepted by their Japanese readers. One student was afraid that the temptation to plagiarize in the Japanese university might be difficult to resist. These students' concerns were consistent with earlier discussions about whether English writing conventions should be accepted in the academic writing of various first or local languages (Eggington, 1987; Shi, in press).

\section{Conclusion}

This study analyzed interview data from 23 Japanese exchange students and two pieces of their writing at different stages of their study in a large Canadian university. Findings suggest that most participants (18) used more words of their own in the second drafts compared with their first drafts, which contained many strings of words directly copied from source texts. Most of the students (15) also said they revised their first drafts to follow the direct and linear English rhetoric pattern. As a result of an eight-month immersion in an English university, many participants found the English rhetoric pattern preferable to the indirect and nonlinear Japanese style. Students' comments, however, varied on how they would write after returning to their Japanese university. Although some said they would either switch between the two writing styles (5) or return to the Japanese style (5), most participants (13) said they would follow the English style when writing in Japanese. The findings of how these students adopted English writing conventions and whether they believed that they would use them when they returned to Japan suggest an impact of English training on the participants' academic writing not only in English but also in Japanese.

This study contributes to our understanding of the extent to which international students are acculturated into the English academy as a result of an eight-month academic immersion in an English-speaking university. Describing and analyzing learning from the students' perspective, the study suggests that academic staff should be aware that international students might bring with them perspectives and traditions of written communication that differ from those of English. They should understand not only what these second language students lack, but also, as Zamel (1997) describes, the dynamic adaptation process "involving active engagement and resistance" (p. 350) as they learn to follow English writing conventions. As indicated by some of the participants in this study, international students may also be concerned about the impact of the English writing style on their first-lan- 
guage writing practices. Eight months of English immersion training in Canada has left many of the Japanese students in a dilemma as to which writing convention to follow when they return home where they will write mostly in Japanese, but also in English. An open forum is recommended for students and teachers to share their views and comparisons of learning experiences and writing conventions between English and their first languages. Students should also exchange and discuss their concerns and choices about which format to follow. In so doing, teachers and students can work together to explore cross-culturally acceptable writing conventions.

However informative our findings, we are aware of the limitations of this relatively small and exploratory study. First of all, the use of two types of tasks (opinion and summary) instead of one may have had an impact on the oral reports and written texts produced by the students. Further, because the interviews were conducted in English, we do not know how much information was lost because of the language proficiency or otherwise of the students. The e-mail comments were also limited as we did not have a chance to verify them when most students were preparing to leave at the end of the program. Finally, the study documents only students' perceptions of what they would do when returning home. Follow-up studies need to determine whether they will follow their original intentions.

\section{Acknowledgment}

This research project is funded by Faculty Research Development Funds from the University of British Columbia granted to the first author. We wish to thank the participating students, research assistants Joe Greenholtz, Sheri Wenman, and Guoqing Feng, and the three anonymous reviewers as well as Pat Mathews for their valuable feedback on earlier drafts of the article.

\section{The Authors}

Ling Shi is an assistant professor in the Department of Language and Literacy Education, University of British Columbia. Her research interests include second-language writing, language testing, and English for specific purposes.

Gulbahar Beckett is an assistant professor in the College of Education Literacy/TESL program, University of Cincinnati, Ohio. She studied and taught at the university of British Columbia, Canada. Thanks to her colleagues and students, her research area now includes second-language writing.

\section{References}

Berwick, R., \& Carey, S. (2000). The interaction of gender and identity: A 6-year perspective on Japanese participants in an academic year aboard. Polyglossia, 3, 39-52.

Biskup, M., \& Wekesser, C. (1992). (Eds.). Suicide: Opposing viewpoints. San Diego, CA: Greenhaven Press.

Bloch, L., \& Chi, L. (1995). A comparison of the use of citations in Chinese and English academic discourse. In D. Belcher \& G. Braine (Eds.), Academic writing in a second language: Essays on research and pedagogy (pp. 231-274). Norwood, NJ: Ablex. 
Campbell, C. (1990). Writing with others' words: Using background reading text in academic compositions. In B. Kroll (Ed.), Second language writing (pp. 211-230). Cambridge, UK: Cambridge University Press.

Carson, J., \& Kuehn, P. (1992). Evidence of transfer and loss in developing second language writers. Language Learning, 42, 157-823.

Clyne, M.G. (1987). Cultural differences in the organization of academic texts. Journal of Pragmatics, 11, 211-247.

Connor, U. (1999). Learning to write academic prose in a second language: A literacy autobiography. In G. Braine (Ed.), Non-native educators in English language teaching (pp. 29-42). Mahwah, NJ: Erlbaum.

Connor, U.M., \& Kramer M.G. (1995). Writing from sources: Case studies of graduate students in business management. In D. Belcher \& G. Braine (Eds.), Academic writing in a second language: Essays on research and pedagogy (pp. 155-182). Norwood, NJ: Ablex.

Cumming, A. (1989). Writing expertise and second-language proficiency. Language Learning, $39,81-141$.

Currie, P. (1998). Staying out of trouble: Apparent plagiarism and academic survival. Journal of Second Language Writing, 7, 1-18.

Eggington, W.G. (1987). Written academic discourse in Korean: Implications for effective communication. In U. Connor \& R. B. Kaplan (Eds.), Writing across languages: Analysis of L2 text (pp. 153-167). Reading, MA: Addison-Wesley.

Halimah, A.M. (2001). Rhetorical duality and Arabic speaking EST learners. English for Specific Purposes, 20, 111-139.

Hinds, J. (1983). Contrastive rhetoric: Japanese and English. Text, 3, 183-195.

Hinds, J. (1987). Reader versus writer responsibility: A new typology. In U. Connor \& R.B. Kaplan (Eds.), Writing across languages: Analysis of L2 text (pp. 141-152). Reading, MA: Addison-Welsey.

Johns, A.M. (1991). Interpreting an English competency examination: The frustration of an ESL science student. Written Communication, 3, 379-401.

Jones, H. (1997). Returning home after studying abroad. Language Teacher, 21, 31-37.

Kachru, Y. (1995). Contrastive rhetoric in world English. English Today, 41, 21-31.

Kaplan, R.B. (1966). Cultural thought patterns in inter-cultural education. Language Learning, $16,1-20$.

Kirkpatrick, A. (1997). Traditional Chinese text structures and their influence on the writing in Chinese and English of contemporary Mainland Chinese students. Journal of Second Language Writing, 6, 223-244.

Kubota, R. (1997). A reevaluation of the uniqueness of Japanese written discourse. Written Communication, $14,460-481$.

Leki, I. (1995). Coping strategies of ESL students in writing tasks across the curriculum. TESOL Quarterly, 29, 235-60.

Leki, I. (1997). Cross-talk: ESL issues and contrastive rhetoric. In C. Severino, J.C. Butler, \& J.E. Bulter (Eds.), Writing in multicultural settings (pp. 234-244). New York: Modern Language Association of America.

Matalene, C. (1985). Contrastive rhetoric: An American writing teacher in China. College English, 47, 789-808.

Mohan, B.A., \& Lo, W.A.Y. (1985). Academic writing and Chinese students: Transfer and developmental factors. TESOL Quarterly, 19, 515-34.

Pennycook, A. (1996). Borrowing others' words: Text, ownership, memory, and plagiarism. TESOL Quarterly, 30, 210-230.

Ray, R. (1990). Language and literacy from the student perspective: What we can learn from the long-term case study. In D. A. Daiker \& M. Morenberg (Eds.), The writing teacher as researcher: Essays in the theory and practice of class-based research (pp. 321-335). Portsmouth, $\mathrm{NH}$ : Boynton Cook. 
Sasaki, M. (2000). Toward an empirical model of EFL writing processes: An exploratory study. Journal of Second Language Writing, 9, 259-291.

Scarcella, R.C. (1984). How writers orient their readers in expository essays: A comparative study of native and non-native English writers. TESOL Quarterly, 18, 671-688.

Shi, L. (in press). How western-trained Chinese TESOL professionals publish in their home environment. TESOL Quarterly.

Smoke, T. (1994). Writing as a means of learning. College ESL, 4, 1-11.

Spack, R. (1997). The acquisition of academic literacy in a second language: A longitudinal case study. Written Communication, 14, 3-62.

Taylor, G., \& Chen, T. (1991). Linguistic cultural and subcultural issues in contrastive discourse analysis: Anglo-American and Chinese scientific texts. Applied Linguistics, 12, 379-336.

Thatcher, B.L. (2000). L2 professional writing in a US and South American context. Journal of Second Language Writing, 9, 41-70.

Vassileva, I. (2001). Commitment and detachment in English and Bulgarian academic writing. English for Specific Purposes, 20, 83-102.

Zamel, V. (1997). Toward a model of transculturation. TESOL Quarterly, 31, 341-352.

\section{Appendix \\ Summary/Opinion Task}

The following are excerpts from two articles with opposing views on the topic of whether physicians can ethically assist suicide. Write either a summary of the two excerpts or an opinion essay stating your own opinion on the topic using the excerpts as sources. Your writing should be about 200-300 words in length.

\section{Excerpt One. Physicians Can Ethically Assist in Suicide}

Sidney H. Wanzer et al.

In the patient whose dying process is irreversible, the balance between minimizing pain and suffering and potentially hastening death should be struck clearly in favor of pain relief. Narcotics or other pain medications should be given in whatever dose and by whatever route is necessary for relief. It is morally correct to increase the dose of narcotics to whatever dose is needed, even though the medication may contribute to the depression of respiration or blood pressure, the dulling of consciousness, or even death, provided the primary goal of the physician is to relieve suffering. The proper dose of pain medication is the dose that is sufficient to relieve pain and suffering, even to the point of unconsciousness. The principles of medical ethics are formulated independently of legal decisions, but physicians may fear that decisions about the care of the hopelessly ill will bring special risks of criminal charges and prosecution.... The physician should follow these principles without exaggerated concern for legal consequences, doing whatever is necessary to relieve pain and being comfort, and adhering to the patient's wishes as much as possible. To withhold any necessary measure of pain relief in a hopelessly ill person out of fear of depressing respiration or of possible legal repercussions is unjustifiable.

(Biskup \& Wekesser, 1992) 


\section{Excerpt Two. Physicians Cannot Ethically Assist in Suicide}

David Orentlicher

This long-standing rejection of assisted suicide reflects a number of concerns with assisted suicide. A patient contemplating assisted suicide will naturally want to discuss that possibility with his or her physician. If the physician appears sympathetic to the patient's interest in suicide, it may convey the impression that the physician feels assisted suicide is a desirable alternative. Such an impression may not be very comforting to the patient. Moreover, if the patient decides to reject suicide, will the patient have the same degree of confidence in the physician's commitment to his or her care as previously? In short, assisted suicide might seriously undermine an essential element of patient-physician relationship.

Patients who are enfeebled by disease and devoid of hope may choose assisted suicide not because they are really tired of life but because they think others are tired of them. Some patients, moreover, may feel an obligation to choose death to spare their families the emotional and financial burden of their care.

Finally, assisted suicide is problematic in terms of its implementation. For many patients, the progression of disease will result in the impairment of decision-making capacity, either from the effects of the disease itself or those of drug treatment. Consequently, it may be difficult to ensure that a competent decision is being made... At what point in the contemplation of suicide by the patient, for example, can the physician be confident that the patient has made a firm decision to end his or her life. (Biskup \& Wekesser, 1992) 